\begin{tabular}{|l|l|l||}
\hline \multicolumn{2}{|c|}{ PublisherInfo } \\
\hline \hline PublisherName & $:$ & BioMed Central \\
\hline \hline PublisherLocation & $:$ & London \\
\hline \hline PublisherImprintName & $:$ & BioMed Central \\
\hline \hline
\end{tabular}

\title{
Rearranging kinetochores
}

\begin{tabular}{|l|l|l||}
\hline \multicolumn{2}{|c|}{ ArticleInfo } \\
\hline \hline ArticleID & $:$ & 3833 \\
\hline \hline ArticleDOI & $:$ & $10.1186 /$ gb-spotlight-20001116-01 \\
\hline \hline ArticleCitationID & $:$ & spotlight-20001116-01 \\
\hline \hline ArticleSequenceNumber & $:$ & 270 \\
\hline \hline ArticleCategory & $:$ & Research news \\
\hline \hline ArticleFirstPage & $:$ & 1 \\
\hline \hline ArticleLastPage & $:$ & 2 \\
\hline \hline & $:$ & RegistrationDate : 2000-11-16 \\
ArticleHistory & $:$ & OnlineDate \\
\hline \hline ArticleCopyright & $:$ & BioMed Central Ltd2000-11-16 \\
\hline \hline ArticleGrants & $:$ & \\
\hline \hline ArticleContext & $:$ & 130591111 \\
\hline \hline
\end{tabular}


William Wells

Email:wells@biotext.com

Rsc is a member of the SWI/SNF family of chromatin-remodeling complexes in yeast. Unlike the main yeast SWI/SNF complex, Rsc is required for progress through mitosis, and absence of Rsc function alters the chromatin structure of yeast centromeres. This could be explained if Rsc was necessary for the transcription of certain mitotic genes, but in the November 21 Proceedings of the National Academy of Sciences, Xue et al. propose that Rsc's effect on centromeres may be direct (Proc. Natl. Acad. Sci. USA 2000, 97:13015-13020). They isolate BAF180, a unique component of the PBAF (Polybromo, BRG1-associated factors) or human Rsc complex. PBAF is localized at kinetochores in prometaphase cells or in the presence of the anti-microtubule drug nocodazole. Thus PBAF/Rsc activity may be needed at kinetochores to create an altered chromatin structure suitable for spindle attachment.

\section{References}

1. RSC, an essential, abundant chromatin-remodeling complex.

2. Stimulation of GAL4 derivative binding to nucleosomal DNA by the yeast SWI/SNF complex.

3. A mutation in NPS1/STH1, an essential gene encoding a component of a novel chromatinremodeling complex RSC, alters the chromatin structure of Saccharomyces cerevisiae centromeres.

4. Proceedings of the National Academy of Sciences, [http://www.pnas.org/]

This PDF file was created after publication. 